\begin{tabular}{|lll}
\hline 45 Jurnal Teknologi Kimia Unimal & $\begin{array}{l}\text { Jurnal } \\
\text { Teknologi } \\
\text { Kimia } \\
\text { Unimal }\end{array}$ \\
\hline
\end{tabular}

\title{
UJI MEKANIK KOMPOSIT SERAT DAUN NENAS BERMATRIK RESIN GETAH PINUS
}

\author{
Zulmiardi $^{1}$, Muhammad Sayuthi ${ }^{1}$, Ferri Safriwardy ${ }^{1}$, Meriatna $^{2}$ \\ ${ }^{1}$ Jurusan Teknik Mesin, Fakultas Teknik, Universitas Malikussaleh \\ ${ }^{2}$ Jurusan Teknik Kimia, Fakultas Teknik, Universitas Malikussaleh \\ Kampus Utama Cot Teungku Nie Reuleut, Muara Batu, Aceh Utara - 24355 \\ Korespondensi: HP: 085260811020, e-mail: muhd.sayuthi@unimal.ac.id
}

\begin{abstract}
Abstrak
Penelitian ini bertujuan untuk menguji pemakaian serat daun nenas terhadap kekuatan tarik komposit berpenguat resin getah pinus pada kondisi beban tarik optimum untukmenghasilkan kekutan tarik pada masing-masing variasi arah serat acak dan ayaman. Penelitian dilakukan secara kontinyu dengan alat mesin uji tarik Multi Testing Machine (MTM). Variabel yang digunakan serat susunan acak dan anyaman dengan ststandar specimen ASTMD 638-02 tipe 4 dengan dimensi specimen ( $p=110 \mathrm{~cm}, L=19 \mathrm{~cm}$, dan tebal $t=5 \mathrm{~cm}$ ). Pengujian yang dilakukan pada penelitian ini antara lain pengujian tarik berdasarkan susunan laminat acak, anyaman dan photomakro. Hasil yang didapatkan dalam penilitian ini, susunan manufaktur yang tepat pada komposit serat nanas dengan susunan laminat acak dengan nilai kekuatan tarik rata-rata sebesar $148.14 \mathrm{MPa}$, sedangkan untuk susunan anyaman memiliki kekuatan tarik 112.26. Hasil penilitian ini kekuatan tarik optimasi fraksi volume 20\%, 30\% dan 40\% bermatrik resin getah pinus dapat di ketahui bahwa susunan laminat acak lebih unggul dari susunan anyaman. Hasil photomakro pada penampang patahan komposit serat nanas terdapat karakteristik patahan yang khas yaitu terdapat serabut serat yang tertarik keluar (Fiber Pull Out).
\end{abstract}

Kata kunci: $\quad$ serat alam, serat nenas, resin, getah pinus, uji mekanik, komposit.

\section{Pendahuluan}

Pemanfaatan Material komposit merupakan material yang terbentuk dari kombinasi antara dua atau lebih material pembentuknya melalui pencampuran yang tidak homogen, dimana sifat mekanik dari masing-masing material pembentuknya berbeda. Komposit serat merupakan bahan komposit yang paling sering dan paling banyak digunakan. Sehingga jika dikatakan bahan komposit, pasti asumsi yang muncul adalah bahan komposit serat. Komposit serat terdiri dari 
beberapa penyusun, salah satunya adalah serat. Keunggulan yang dimiliki oleh serat alam antara lain : non-abbrasive, densitas rendah, harga lebih murah, ramah lingkungan, dan tidak membahayakan bagi kesehatan. Penggunaan serat alam sebagai filler dalam komposit tersebut terutama untuk lebih menurunkan biaya bahan baku dan peningkatan nilai salah satu produk pertanian (Kunarto, 2016). Serat dapat digolongkan dalam dua jenis yaitu : serat sintetis dan serat alam. Serat sintetis adalah serat buatan dimana dibuat dari campuran bahan kimia atau membutuhkan teknologi khusus. Sedangkan serat alam adalah serat yang diperoleh di alam sekitar kita yang berasal dari tumbuh-tumbuhan, hewan dan mineral. Serat yang berasal dari tumbuhan adalah serat pelepah pisang, serat nanas, serat rami, serat ampas tebu dan lain-lain.Serat yang berasal dari hewan adalah bulu domba, kulit, dan sutera.Serat yang berasal dari mineral adalah serat yang terbuat dari kuarsa, contohnya seperti kaca serat atau fiberglass (Lambok Silalahi, 2016). Getah yang dihasilkan Pinus merkusi digolongkan sebagai oleoresin. Oleoresin merupakan cairan asam-asam resin yang menetes keluar apabila saluran pada kayu atau kulit pohon jenis daun jarum tersayat atau pecah (Hillis, 1987).

Penelitian terdahulu tentang komposit serat alam (komposit polimer) antara lain mempelajari pengaruh variasi panjang serat nanas terhadap kekuatan tarik komposit polyester - serat nanas. Metode yang digunakan dalam penelitian ini yaitu metode eksperimen dengan melakukan pengujian tarik berdasarkan standar ASTM D638. Variabel bebas dalam penelitian ini adalah variasi panjang serat nanas yaitu $0.5 \mathrm{~cm}, 1.0 \mathrm{~cm}, 1.5 \mathrm{~cm}$ dan $2.0 \mathrm{~cm}$. Pembuatan spesimen dilakukan dengan pencampuran resin polyester 157 BQTN-EX, serat nanas sebesar $2 \%$ dan katalis $1 \%$. Serat nanas sebelumnya melalui proses perendaman $\mathrm{NaOH} 30 \%$ selama 2 jam dengan tujuan mengurangi kandungan lignin dan meningkatkan ketahan serat. Hasil penelitian menunjukan ada pengaruh pemberian variasi panjang serat nanas terhadap kekuatan tarik komposit polyester - serat nanas dimana kekuatan tarik tertinggi pada serat panjang $2 \mathrm{~cm}$ yaitu $25.17 \mathrm{~N} / \mathrm{mm}^{2}$. (Dita Novi Susanti., 2018). 
Berdasarkan uraian di atas maka perlu dilakukan penelitian lebih lanjut untuk mengetahui kekuatan tarik komposit serat daun nanas menggunakan resin getah pinus dengan susunan arah serat laminat acak dan anyaman.

\section{Bahan dan Metode}

Bahan yang digunakan dalam penelitian ini adalah sebagai berikut: Serat Nanas, Resin Getah Pinus, katalis Mexpo dan Larutan $\mathrm{NaOH}$.

Peralatan yang diperlukan dalam penelitian ini antara lain adalah Cetakan kaca dengan ketebalan $5 \mathrm{~mm}$. Alat bantu lainyaitu : sendok, cutter, gunting, kuas, pisau, spidol, oli/grease, penggaris dan gergaji potong, Alat bantu (sendok, cutter, gunting, kuas, pisau, spidol, oli/grease, penggaris dan gergaji potong), gerinda pemotong dan amplas, mesin uji tarik Universal Testing Machine, miroskop digital.

\section{Metode}

Proses pembuatan komposit serat nanas dengan matrik getah pinus adalah. dengan ukuran panjang cetakan dengan susunan Laminat acak dan anyaman. Ukuran cetakan spesimen menggunakan kaca ketebalan $5 \mathrm{~mm}$, ukuran cetakan adalah panjang $20 \mathrm{~cm}$, lebar $15 \mathrm{~cm}$ dan tebal $4 \mathrm{~mm}$. Resin getah pinus dicampur dengan katalis untuk membantu proses pengeringan. Katalis yang digunakan sebanyak $1 \%$ dari banyaknya resin getah pinus yang digunakan. Proses pengeringan dilakukan sampai benar-benar kering yaitu 5 - 10 jam Proses pengambilan komposit dari cetakan yaitu menggunakan pisau. Melakukan proses curing selama 9 jam. Benda uji komposit siap untuk dipotong menjadi spesimen benda uji.

Pengujian tarik dilakukan untuk mengetahui besarnya kekuatan tarik dari bahan komposit.Pengujian dilakukan dengan mesin uji "Universal Testing Machine" buatan jepang. Spesimen pengujian tarik di bentuk menurut standar ASTM D 638-02 tipe 4 yang ditunjukkan pada gambar 1 berikut: 


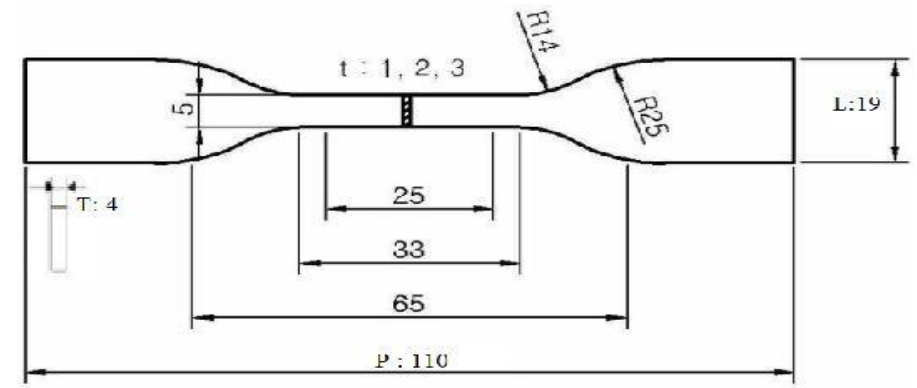

Gambar 1. Bentuk sampel uji tarik dengan strandar ASTM D 638-02 tipe 4 Dimana:

$\mathrm{P}$ : Panjang total spesimen $(\mathrm{mm}) \mathrm{L} \quad$ : Lebar $\mathrm{mm}) \mathrm{T} \quad$ : Tebal (mm)

Selanjutnya dilakukan photo makro untuk mengetahui kegagalan yang terjadi pada komposit. Selain itu, foto makro juga dilakukan untuk melihat karakteristik patahan hasil pengujian tarik pada komposit.

\section{Hasil dan Diskusi}

\subsection{Pengujian Tarik}

Berdasarka $\mathrm{n}$ pengujian terhadap empat spesimen masing masing untuk fraksi volume $20 \%$, 30\% dan 40\% didapatkan bahwa adanya kekuatan tarik yang berbeda-beda sesuai dengan fraksi volume komposit tersebut. Kekuatan tarik tersebut sangat dipengaruhi oleh fraksi volume dan susunan serat sehingga dengan meningkatnya fraksi volume pada masing masing specimen maka akan meningkat pula kekuatan tarik komposit tersebut.

Susunan serat merupakan hal yang paling menentukan hasil dari kekuatan tarik dan kekuatan luluh pada komposit, dapat kita lihat bahwa hasil dari pengujian tarik komposit susunan serat laminat acak dan anyaman memiliki peningkatan nilai sesuai dengan fraksi volume tersebut. Pada . Berikut bentuk grafik hubungan kekuatan tarik dan regangan serat nanas susunan laminat acak dan anyaman optimasi fraksi volume serat 20\%, 30\% dan $40 \%$ seperti ditunjukkan pada Gambar 2 sampai Gambar 4. 


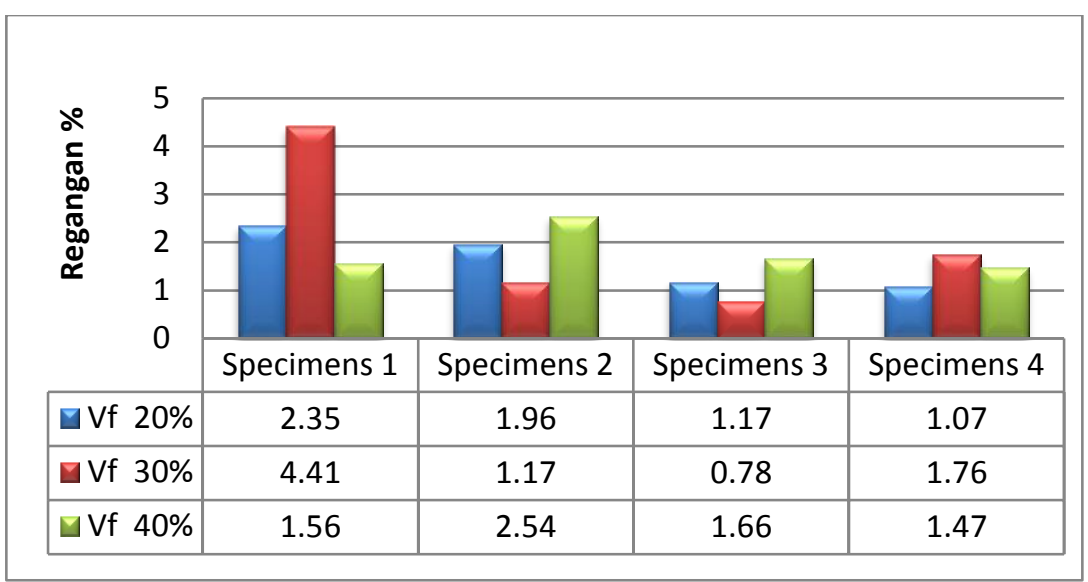

Gambar 2. Grafik hubungan tegangan tarik komposit serat nanas susunan Laminat acak dengan fraksi volume $20 \%, 30 \%$ dan $40 \%$.

Gambar 2 dapat kita lihat bahwa komposit susunan serat laminat acak dengan fraksi volume $20 \%$ mempunyai nilai hasil kekuatan tarik tertinggi yaitu 1,76 MPa pada spesimen 3, untuk fraksi volume 30\% di dapatkan kekuatan tarik tertinggi 4.41 MPa pada specimen 1, dan untuk fraksi volume $40 \%$ di dapatkan hasil kekuatan tarik tertinggi 2.54 pada specimen 2

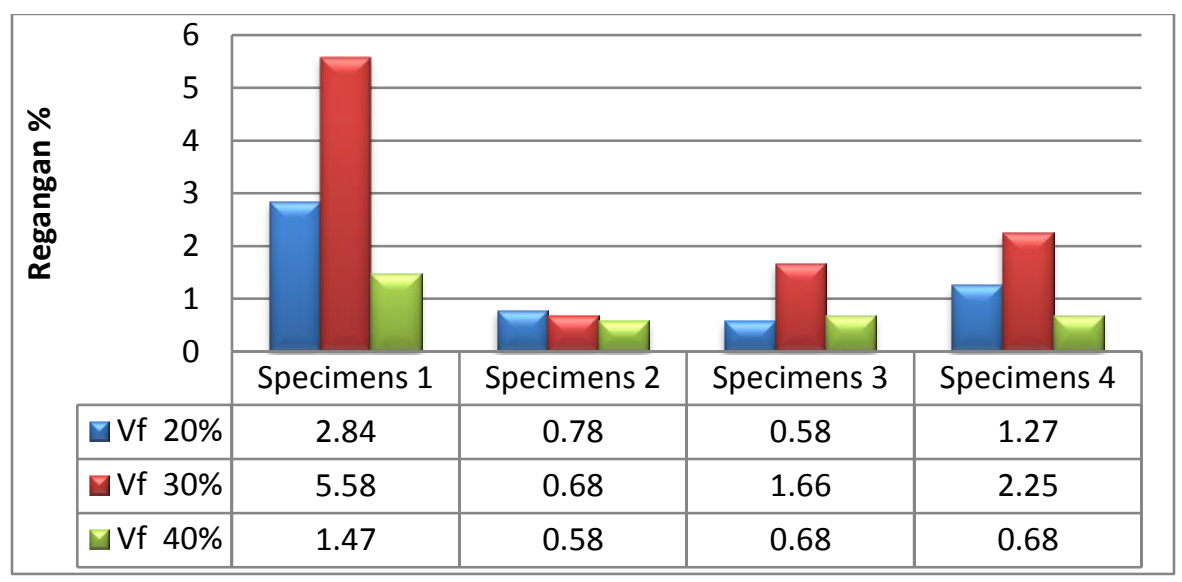

Gambar 3. Kurva regangan tarik komposit serat nanas susunan Laminat acak dengan fraksi volume $20 \%, 30 \%$ dan $40 \%$.

Gambar 3 dapat kita lihat bahwa komposit susunan serat laminat acak dengan fraksi volume $20 \%$ mempunyai nilai hasil kekuatan tarik tertinggi yaitu 2,84 MPa pada spesimen 1, untuk fraksi volume 30\% di dapatkan kekuatan tarik 
tertinggi 5.58 MPa pada specimen 1, dan untuk fraksi volume $40 \%$ di dapatkan hasil kekuatan tarik tertinggi 1.47 pada specimen 1

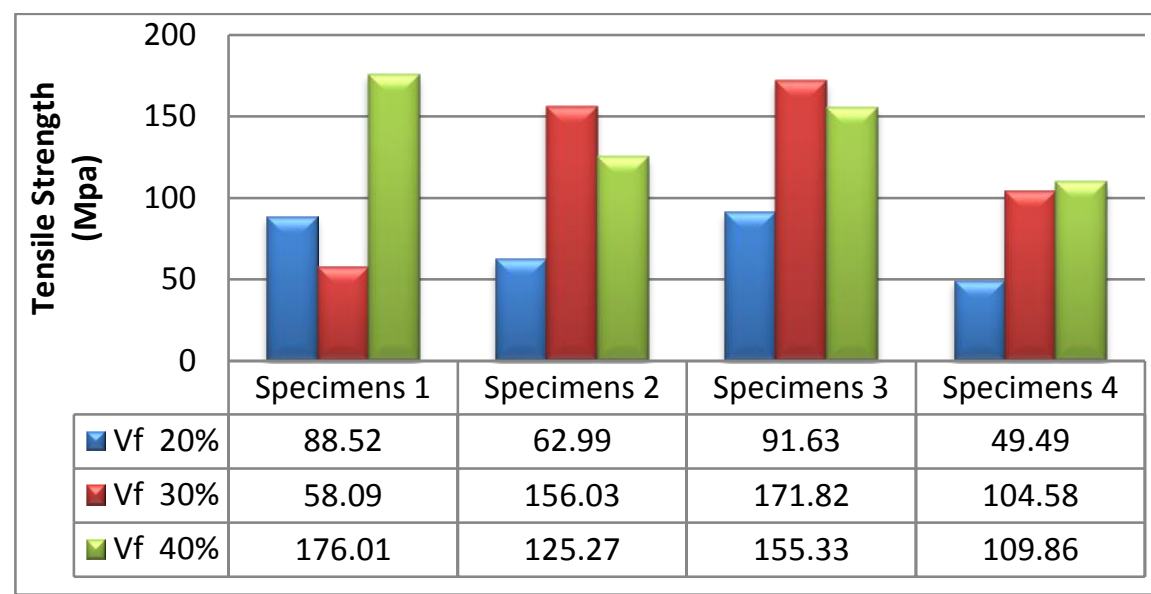

Gambar 4.Grafik hubungan tegangan tarik komposit serat nanas susunan anyaman dengan fraksi volume $20 \%, 30 \%$ dan $40 \%$.

Gambar 4 dapat kita liat bahwa susunan serat anyaman terjadi penurunan nilai kekuatan tarik. Fraksi volume 20\% susunan serat acak mempunyai nilai hasil kekuatan tarik tertinggi yaitu 91.63 MPa pada spesimen 3, untuk untuk fraksi volume 30\% di dapatkan kekuatan tarik tertinggi $171.82 \mathrm{MPa}$ pada specimen 3, dan fraksi volume $40 \%$ di dapatkan hasil kekuatan tarik tertinggi 176.01 pada specimen 1.

Berikut Histogram hubungan kekuatan tarik rata-rata komposit serat nanas susunan laminat acak dan anyaman dan perbandingan kekuatan tarik dari perbedaan variasi susunan serat optimasi fraksi volume serat $20 \%, 30 \%$ dan $40 \%$ pada Gambar 5 sampai 7.

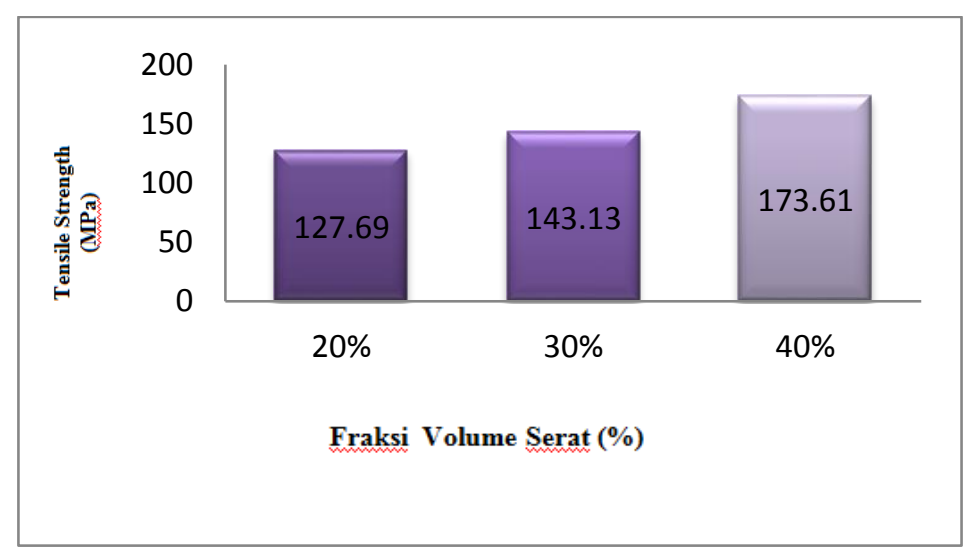


Gambar 5. Histogram kekuatan tarik berdasarkan volume 20\%, 30\% dan $40 \%$ komposit serat nanas susunan laminat acak

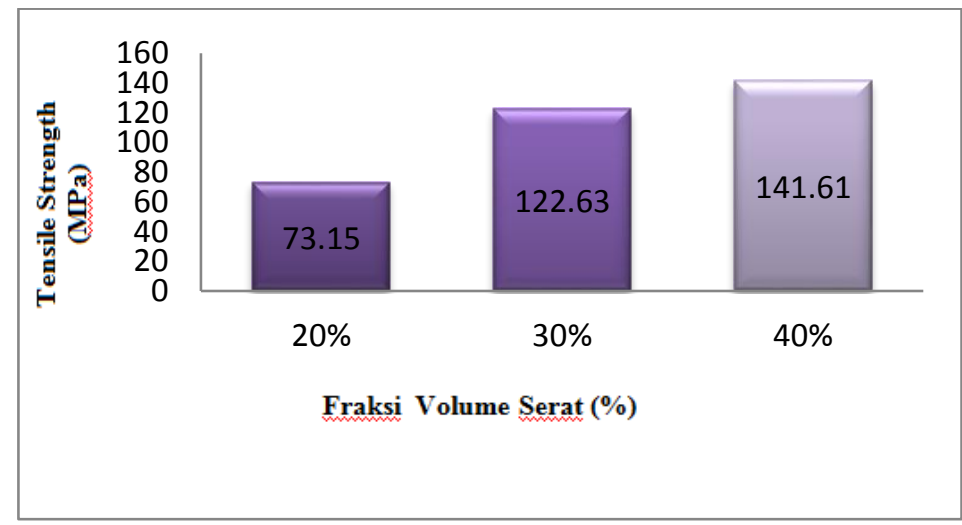

Gambar 6. Histogram kekuatan tarik berdasarkan volume 20\%, 30\% dan $40 \%$ komposit serat nanas susunan anyaman

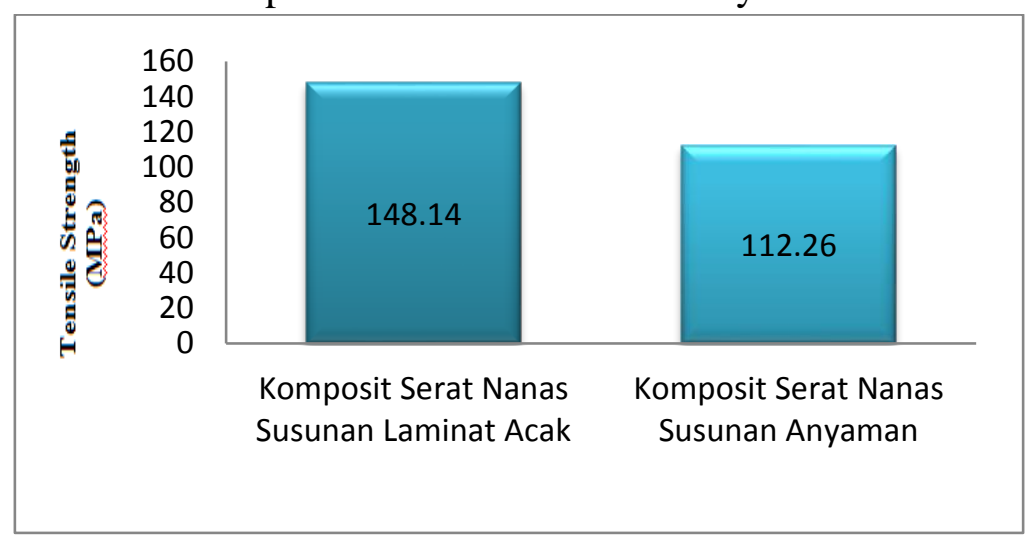

Gambar 7. Histogram perbandingan kekuatan tarik komposit berdasarkan susunan laminat acak dan anyaman optimasi fraksi volume 20\%, 30\% dan $40 \%$

Berdasarkan hasil pengujian tarik yang telah dilakukan terhadap komposit serat nanas dengan variasi susunan serat laminat acak dan anyaman dengan optimasi volume $20 \%, 30 \%$ dan $40 \%$ didapatkan bahwa kekuatan tarik komposit serat nanas susunan laminat acak memiliki hasil nilai tertinggi yaitu 148.14 dan komposit serat nanas susunan anyaman memiliki kekuatan tarik yaitu 112.26 MPa. Histogram perbandingan kekuatan tarik diatas dapat kita simpulkan bahwa kekuatan tarik komposit serat nanas dengan susunan laminat acak lebih meningkat dibandingkan dengan komposit serat nanas susunan anyaman. Penurunan nilai hasil uji tarik serat nanas susunan anyaman disebabkan oleh factor susunan tersebut. Factor utama yang terjadi pada komposit susunan anyaman yaitu 
kurangnya kemampuan perekat dari matrik disebabkan oleh susunan yang tidak searah.

\subsection{Pengamatan Makro}

Dari hasil pengujian tarik kompsit berpenguat serat nanas susunan laminat acak dan anyaman dapat dilihat beberapa bentuk patahan spesimen yang beragam. Kondisi ini tentu dipengaruhi oleh susunan serat dan fraksi volume, adanya ikatan yang kuat antara serat dan matrik akan membuat bentuk patahan spesimen yang lebih rapi dan permukaan patah yang cenderung rata. Untuk mengamati bentuk patahan pada masing- masing spesimen akibat dilakukan pengujian tarik maka dilakukan pengamatan visual (foto makro) pada masing-masing permukaan patahan spesimen. Tujuan dilakukan foto makro adalah untuk mengetahui kegagalan yang terjadi pada komposit. Selain itu, foto makro juga dilakukan untuk melihat karakteristik patahan hasil pengujian tarik pada komposit.

Pada penampang patahan komposit serat nanas terdapat karakteristik patahan yang khas yaitu terdapat serabut serat yang tertarik keluar (Fiber Pull Out). Hal ini dikarenakan adanya pelepasan serat dari matrik sebelum komposit patah pada waktu pengujian tarik. Pada daerah yang mempunyai ikatan adhesi paling lemah antara serat dan matrik dalam komposit menyebabkan serat terlepas dari matriknya sehingga mengakibatkan pull out. Berikut ini adalah gambar patahan makro hasil pengujian tarik seperti ditunjukkan pada gambar 8 sampai dengan 15.

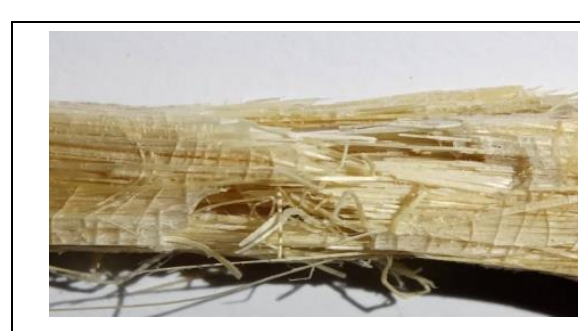

Gambar 8. Hasil patahan spesimen pada uji tarik dengan fraksi volume $20 \%$ Laminat Acak

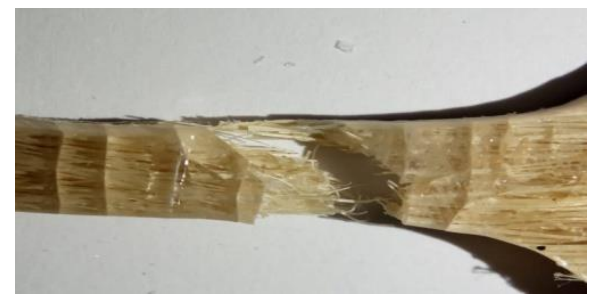

Gambar 9. Hasil patahan spesimen pada uji tarik dengan fraksi volume $30 \%$ Laminat Acak 


\begin{tabular}{|l|l|}
\hline $\begin{array}{l}\text { Gambar 10.Hasil patahan spesimen } \\
\text { pada uji tarik dengan fraksi volume } \\
\text { 40\% Laminat Acak }\end{array}$ & $\begin{array}{l}\text { Gambar 11. Hasil patahan spesimen } \\
\text { pada uji tarik dengan fraksi volume } \\
20 \% \text { susunan ayaman. }\end{array}$ \\
\hline $\begin{array}{l}\text { Gambar 12. Hasil patahan } \\
\text { spesimen pada uji tarik dengan } \\
\text { fraksi volume } 30 \% \text { susunan } \\
\text { ayaman }\end{array}$ & $\begin{array}{l}\text { Gambar 13. Hasil patahan spesimen } \\
\text { pada uji tarik dengan fraksi volume } 40 \\
\text { susunan ayaman. }\end{array}$ \\
\hline
\end{tabular}

\section{Simpulan}

Hasil penelitian ini dapat disimpulkan sebagai berikut :

1. Kekuatan tarik komposit serat nanas susunan Laminat acak fraksi volume $20 \%$, $30 \%$ dan $40 \%$ memiliki kekuatan tarik tertinggi pada fraksi volume $40 \%$ dengan nilai rata-rata sebesar $\sigma=173.61 \mathrm{MPa}$, regangan tarik $\varepsilon=0.85 \%$. Kekuatan tarik terendah pada fraksi volume $=20 \%$ dengan nilai rata-rata sebesar $\sigma=127.69 \mathrm{MPa}$, regangan tarik sebesar $\varepsilon=1.36 \%$. Pada fraksi volume 20\%, 30\% dan 40\% kekuatan tarik komposit mengalami peningkatan sesuai dengan persentase fraksi volume, kekuatan tarik persentase fraksi volume $20 \%$ menuju fraksi volume $30 \%$ sebesar $15,44 \%$, fraksi volume $30 \%$ menuju fraksi volume $40 \%$ sebesar $30,48 \%$. Nilai terbaik diperoleh pada fraksi volume $40 \%$ sebesar $\sigma=173.61 \mathrm{MPa}$.

2. Kekuatan tarik komposit serat nanas sususan anyaman fraksi volume $20 \%$, $30 \%$ dan $40 \%$ memiliki kekuatan tarik tertinggi pada fraksi volume $40 \%$ 
dengan nilai rata-rata sebesar $\sigma=141.61 \mathrm{MPa}$, regangan tarik $\varepsilon=1.80 \%$. Kekuatan tarik terendah pada fraksi volume $20 \%$ dengan nilai rata-rata sebesar $\sigma=73.15 \mathrm{MPa}$, regangan tarik sebesar $\varepsilon=4.13 \%$. Pada fraksi volume $20 \%$, $30 \%$ dan $40 \%$ mengalami peningkatan sesuai dengan persentase fraksi volume, peningkatan kekuatan tarik fraksi volume $20 \%$ menuju fraksi volume $30 \%$ sebesar 49,48\%, persentase fraksi volume 30\% menuju fraksi volume $40 \%$ sebesar $18,98 \%$. Nilai terbaik diperoleh pada fraksi volume $40 \%$ sebesar $\sigma=$ 141.61MPa.

3. Hasil yang didapatkan dalam penilitian ini, susunan manufaktur yang tepat pada komposit serat nanas yaitu dengan susunan laminat acak Dengan nilai kekuatan tarik rata-rata sebesar $148.14 \mathrm{MPa}$. Sedangkan untuk susunan anyaman memiliki kekuatan tarik 112.26. Hasil penilitian ini kekuatan tarik optimasi fraksi volume $20 \%, 30 \%$ dan $40 \%$ bermatrik resin getah pinus dapat kita ketahui bahwa susunan laminat acak jelas lebih unggul dari susunan anyaman.

\section{Daftar Pustaka}

1. STM.D 638-02 "Standart test method for tensile properties of plastics".Philadelphia, PA :American Society for Testing and Materials.

2. Chawala, 1987. "Composite Material frist ed Mechanics". New York : Mc Graw Hill,Inc.

3. Callister, W. D., 2007, "Material Science and Enginering, An Introduction 7ed",Department of Metallurgical Enginering The University of Utah, John Willey and Sons, Inc.

4. Smallman, R. E. dan Bishop, R. J., 2000."Pri Metalurgi Fisik Modern dan Rekayasa Material”. Edisi Keenam, Erlangga, Jakarta.

5. Dita Novi Susanti, 2018. "Pengaruh Variasi Panjang Serat Nanas Terhadap Kekuatan Tarik Dan Impact Komposit Polyester - Serat Nanas". Teknik Mesin Universitas Muhammadiyah Semarang.

6. Delni Sriwita, 2014. "Pembuatan Dan Karakterisasi Sifat Mekanik Bahan Komposit Serat Daun Nenas-Polyester Ditinjau Dari Fraksi Massa Dan Orientasi Serat". Jurusan Fisika FMIPA Universitas Andalas.

7. Hendrikus Wona, 2015. "Pengaruh Variasi Fraksi Volume Serat terhadap Kekuatan Bending dan Impak Komposit Polyester Berpenguat Serat Agave Cantula". LJTMU: Vol. 02, No. 01, April 2015, (39-50). 
8. Lambok Silalahi, 2016. "Pengaruh perlakuan alkali dan pemanasan serat terhadap kekuatan tarik serat lengkuas".Teknik mesin Universitas Lampung.

9. Muhammad azman, 2018."Pengaruh Fraksi Volume Terhadap Kekuatan Tarik Komposit Berpenguat Serat Abaca Menggunakan Resin Bqtn 157Ex”.Teknik Mesin Universitas Malikussaleh.

10. Nayiroh, N. 2013. 'Teknologi Material Komposit Lecture Material". Malang. Universitas Islam Negeri. Malang.

11. Nurdiana, 2013.'Penentuan Kekuatan Tarik Material Komposit Epoxy dengan Pengisi Serat Rockwool Secara Eksperimen”.Jurnal Dinamis Vol.I,No.13.

12. Wibowo P. 2006. Produktifitas Penyadapan Getah Pinus merkusii Jungh.Et de Vriese dengan Sistem Koakan (QUARRE SYSTEM) di Hutan Pendidikan Gunung Walat Kabupaten Sukabumi Jawa Barat. [skripsi]. Bogor: Fakultas Kehutanan. Institut Pertanian Bogor.

13. M. Muhajir, M.A.Mizar, D.A.Sudjimat,and J. P. T. Mesin-ft,"Analisis Kekuatan Tarik Bahan Komposit Matriks Resin,"no.2, pp.1-8,2016

14. D.Indonesia,"Pengaruh Fraksi Volume Serat dan Lama Perendaman Alkali terhadap Kekuatan Impak Komposit Serat Aren- Polyester, "vol.14, no.1, pp.26-32,2011.

15. M.Septiana, P.Sinuhaji, and M.Syukur, "Pembuatan Dan Karakterisasi Komposit Serat Palem Saray Dengan Matriks Poliester,"No.1, 2003.

16. Y.Li,S.Zhu,Y.Feng,F.Xu,J.Ma,andF. Zhong,"Influence ofAlkalization Treatment on the Color Quality and the Total Phenolic and Anthocyanin Contentsin Cocoa Powder," no. February,2013.

17. K.Panyasart, N. Chaiyut, and T. Amornsakchai,"Effect of surfacetreatment on the properties of pineappleleaf fibers reinforced poly amide6 composites," Energy Procedia,vol.56,pp. 406-413,2014.

18. FisikaandF.Universitas,"Pembuatan Dan Karakterisasi SifatMekanik Bahan Komposit Serat Daun Nenas- Polyester Ditinjau Dari Fraksi Massa Dan Orientasi Serat,"vol.3,no.1, pp.30-36,2014.

19. SK.Witono,Y.S.Irawan, R.Soenoko,and H. Suryanto, "Pengaruh Perlakuan Alkali (NaOH) Terhadap Morfologi Dan Kekuatan Tarik Serat Mendong,"Rekayasa Mesin,vol. 4, no.3,p. pp.227-234,2013. I.G.Sudiarsa,T.G.T.Nindhia,andI.W.

20. Surata,"Pengaruh Fraksi Berat Serat Daun Nanas Terhadap Kekuatan Tarik Dan Lentur Komposit Polyester," J.Ilm. Tek. Desain Mek. vol.7, no.2, 2018.

21. R.Marcelino, "the Mechanical Characteristics of Composites Coconut Fibers With the Variation of Direction ofthe Fiber Science and Technology Faculty," 2018. 